\title{
O teologiji na sveučilištu
}

\author{
IVICA RAGUŽ* \\ UDK: 27-1:378 • Izvorni znanstveni rad \\ Primljeno: 16. kolovoza 2017. • Prihvaćeno: 23. studenoga 2017.
}

Sažetak: Članak analizira mjesto i važnost teologije na sveučilištu. Prvi dio, ukazujući na posebnost teologije kao znanosti, određuje istinsko mjesto teologije na sveučilištu, odnosno određuje teologiju kao tuđinku na sveučilištu. Time se želi ukazati da teologija, ukoliko želi ostati vjerna sebi, otuditi se od same sebe i doprinijeti sveučilištu, mora ostati strana tom istom sveučilištu. Pod ovim se vidom ujedno kritički promatra suvremena teološka znanost. Drugi dio clanka pokazuje koji je to poseban doprinos teologije sveučilištu i tako ukazuje na njezinu važnost. Temelj je ovim promišljanjima trostruka Kristova kušnja. Teologija, u prvome redu, čuva filozofsku bit sveučilišta - istraživanje znanja zbog znanja. Takvo se viđenje postavlja protiv uhljebljivanja, funkcionarstva $u$ znanosti, ali $i$ protiv isključivosti filozofijskoga pristupa znanosti, odnosno apsolu-

* Prof. dr. sc. Ivica Raguž, Katolički bogoslovni fakultet u Đakovu Sveučilišta J.J.

Strossmayera u Osijeku, P. Preradovića 17, 31400 Đakovo, Hrvatska, ivica. raguz@os.t-com.hr tiziranja pojedinih znanosti. Filozofijskom pristupu znanosti prijeti i opasnost da iz vida izgubi subjekt istraživanja - čovjeka. Doprinos teologije ovdje se očituje u korektivnoj ulozi koju ima: podsjeća znanosti da iz vida ne izgube ono što ljudskost podrazumijeva - djelovanje i ljubav. Nakana je članka, promišljanjima o teologiji na sveučilištu i njezinu doprinosu, rasvijetliti i pokazati kako teologija jest ili bi trebala biti istinska čuvarica ideje sveučilišta.

Ključne riječi: teologija, sveučilište, znanosti, znanje, djelovanje, ljubav.

\section{Uvod}

U ovome članku namjera nam je ukratko predstaviti ulogu teologije na sveučilištu. Da bi se mogla sagledati cjelovito ta tema, bilo bi nužno prvo definirati teologiju, potom sveučilište te tek u trećem koraku progovoriti o ulozi takve 
teologije na sveučilištu. Posve je razumljivo da to ovdje ne možemo učiniti. O sveučilištu smo već pisali pa smijemo uputiti na naša prijašnja promišljanja. ${ }^{1}$ Stoga ovdje želimo progovoriti o posebnom statusu teologije spram ostalih znanosti na sveučilištu i o njezinom posebnom doprinosu sveučilištu. Naša je teza da bi sveučilište izgubilo svoje izvorno poslanje bez prisutnosti teologije. Dakako, time se podrazumijeva da i teologija treba ostati vjerna svojoj vlastitoj znanstvenoj metodi spram ostalih znanosti. Upravo ćemo s tom temom i započeti ovo naše promišljanje.

\section{Teologija kao tuđinka na sveučilištu}

Poseban znanstveni status teologije spram svih znanosti na sveučilištu, bilo spram onih humanističkih, bilo prirodoslovnih znanosti, možda bi se mogao najbolje sažeti u pojmu: tuđinka. Navest ćemo tri posebnosti teologije kao tuđinke spram ostalih znanosti.

Prvo, teologija je tuđinka spram ostalih znanosti prije svega zbog principa na kojima ona temelji svoju znanstvenu metodu. Naime, kako je to već istaknuo Toma Akvinski, teologija je znanost poput svih ostalih znanosti, ukoliko i ona počiva na principima (dogmama), na temelju kojih sustavno i cjelovito predstavlja sadržaj kršćanske vjere. ${ }^{2}$ Sve znanosti imaju principe ( $\gg$ dogme $\ll$ ), tako i teologija. No, ono po čemu se teologija razlikuje od ostalih znanosti jest u tome što njezini principi nisu razumski dokazivi, kao što je to u svih drugih znanosti, humanističkih i prirodoslovnih. Oni su »posuđeni «, dani od Boga te se kao takvi ne mogu razumski dokazati. U ostalih znanosti ti se principi znanosti mogu dokazati.

Drugo, teologija je također posebna znanost, ukoliko je najsubjektivnija, odnosno najljudskija znanost. Naime, teologija se ne bavi apstraktnim pojmovima niti pukom objektivnom stvarnošću. Ona ima za objekt subjekt, osobu, a to je osobni Bog, troosobni Bog koji se objavljuje u povijesti, koji se objavio u osobi Isusa Krista. Stoga je teologija osobna znanost, a to znači da ona kao uvjet svoje znanstvenosti zahtijeva osobu, osoban pristup, što se zapravo ostvaruje u činu vjere. Naime, teologija jest znanost vjere, a to znači da je temeljni uvjet znanstvenosti teologije vjera, vjera shvaćena kao čin koji zahvaća i zahtijeva cijeloga čovjeka, cjelovitu predanost Bogu, razumom i voljom. $\mathrm{U}$ tom smislu uvjet je znanstvenoga bavljenja teologijom cjeloviti čovjek, odnosno, da bi teolog bio znanstvenik, on mora biti prije svega vjernik, biti potpuno zahvaćen, ili kako kaže sv. Toma, osobno zatočen

\footnotetext{
${ }^{1}$ I. RAGUŽ, Nekoliko crtica o sveučilišnoj teologiji i teološkim časopisima, u: Bogoslovska smotra 81(2011.)1, 147.-153.; ISTI, O »teoriji « i sveučilištu nekoć i danas, u: Diacovensia 19(2011.)3, 383.-391.; ISTI, Epimeteje, Đakovo, 2016., 115.-118.

${ }^{2}$ Više o tome I. RAGUŽ, A. SVIRAĆ, Neki vidovi teologije kao znanosti kod Tome Akvinskoga, u: Diacovensia 24(2016.) 1, 91.-116.
} 
objektom vlastita istraživanja. ${ }^{3}$ Time se također podrazumijeva vjera kao dinamična stvarnost. Vjernik je pozvan stalno rasti u vjeri, a taj se rast tako ostvaruje da se svojom voljom i razumom uvijek iznova suobličuje s Bogom u kojega vjeruje. Iz toga slijedi da teolog može biti dobar znanstvenik samo ako je dobar vjernik, ako što više u ljubavi biva oslobođen egoizma, ako se što više osobno poistovjećuje s osobnim Bogom. Teološki rečeno, teologija zahtijeva svetost, ili filozofski rečeno, nužan preduvjet bavljenja teologijom jest etičnost. Sjajno je to izrekao Franz Rosenzweig koji razlikuje biblijsko mišljenje (teologiju) od filozofskoga mišljenja. ${ }^{4}$ Dok je filozofija samačko mišljenje, »misleće mišljenje $\ll$, u kojemu čovjek polazi od sebe, od svojega razuma, teologija je »mišljenje govora «, mišljenje koje se događa u razgovoru, mišljenje pred Osobom, pred Bogom, mišljenje kao slušanje, mišljenje kao cjelovita predanost Bogu.

Treće, teologija je također posebna znanost, ukoliko je ona znanost koja pretpostavlja i zahtijeva zajednicu, znanost Crkve. Teologija jest znanost vjere, a vjera se u teologiji ne shvaća samo kao čin pojedinca, nego kao čin zajednice onih koji vjeruju, a to je Crkva. Budući da je vjera predanost Bogu, Bog je jedini motiv vjere (credere Deo), tj. Bog je jedini autoritet na temelju kojega se vjeruje u njega: u Boga se ne vjeruje zbog vlastite spoznaje i vlastitih zaključaka, nego zbog samoga Boga. $\mathrm{U}$ tom smislu vjera uvijek podrazumijeva autoritet, autoritet Boga, ali i autoritet Crkve, u kojoj Bog i dalje ostvaruje svoj autoritet spram čovjeka. Stoga je Crkva čuvarica Božje objave, a njezin pak autoritet za teologa predstavlja autoritet same Božje objave. Drugim riječima, teologija ostaje vjerna svojoj znanstvenoj metodi samo ako je crkvena, ako se događa unutar Crkve, unutar žive zajednice onih koji vjeruju i koji slave Gospodina u liturgiji, nauku i uzajamnom služenju. U skladu s time, teologija je znanost koja je upravo zbog te dimenzije crkvenosti posebno svjesna da teolog može pravo pristupiti objektu istraživanja samo u dijalogu i zajedništvu s ostalim teolozima tijekom duge povijesti same Crkve, posebice s onim teolozima koji su upravo zbog svojega svetog (etičkog) života uspjeli spoznati i sustavno ponajbolje prikazati mnoge vidove kršćanske vjere. Zato je teologija na poseban način znanost zajednice.

Sve rečeno, dakako, može se susresti i kod ostalih znanosti. I ostale znanosti, kao što je bilo napomenuto, imaju principe. Također i ostale znanosti pretpostavljaju subjektivnost, predanost objektu istraživanja i etičnost (čestitost), kao i $\gg \mathrm{Crkvu} \ll$,

${ }^{3}$ TOMA AKVINSKI, De veritate 14, 1: »Intellectus credentis dicitur esse captivatus, quia tenetur terminis alienis, et non propriis. II Corinth. X, 5: in captivitatem redigentes omnem intellectum et cetera.« Opširnije vidi I. RAGUŽ, Neki vidovi teologije vjere Tome Akvinskoga, u: Diacovensia 21(2013.)2, 285.-307.

${ }^{4}$ F. ROSENZWEIG, Die Schrift. Aufsätze, Übertragungen und Briefe, Frankfurt am Main, 1964., 200. 
akademsku zajednicu bilo sadašnjih znanstvenika ili onih u prošlosti. No, u teologiji sve su te dimenzije posebno naglašene, odnosno one su conditio sine qua non same teologije, što nije slučaj u ostalih znanosti, kako ćemo to kasnije i pokazati. Dakle, upravo ta činjenica da je teologija znanost vjere i Crkve jest ono što teologiju čini tuđinkom spram svih ostalih znanosti, a time tuđinkom na sveučilištu.

Ipak, teologija je vrlo često kroz povijest, a što je slučaj i danas, taj element otuđenja spram sveučilišta znala ublažavati, relativizirati pa čak i ugrožavati. ${ }^{5}$ Tako se teologija od srednjovjekovlja poimala u skladu s ondašnjim otkrićem filozofije kao neka vrsta filozofske teologije, gdje se o Bogu isključivo promišljalo u kontekstu govora o bitku, spoznaji ili ljubavi. Cijeli se sadržaj vjere nastojao znanstveno sistematizirati unutar takvoga obzorja filozofske znanosti. Kasnije pak u novovjekovlju ideal teologiji jest skolastika, školski sustav, gdje se sadržaji vjere takoreći reduciraju na uobičajene, opće pojmove ostalih znanosti, na opću, svima razumljivu spoznaju. U novije pak vrijeme teologija brani svoju znanstvenost strogom metodologijom, sustavnim prikazom sadržaja vjere, interdisciplinarnošću, a nerijetko i navođenjem po mogućnosti što većega broja literature. Nije teško ne uvidjeti da se teologija na današnjim hrvatskim sveučilištima uglavnom poima skolastički, školski, ili pak kao puka metodologija.

Treba reći da su takvi pristupi teologiji unutar sveučilišta tijekom povijesti imali, te i danas imaju, pozitivnu ulogu za teologiju kao i za druge znanosti. Teologija na sveučilištu, posebno ona skolastički i metodološki koncipirana teologija, ulazi u plodan dijalog s ostalim znanostima, lišava se time opasnosti svakoga fideizma i dogmatizma, a time i sama uspijeva prodrijeti dublje u same sadržaje vjere, služeći se upravo spoznajama drugih znanosti. Isto tako, znanstvenost teologiji omogućuje da ona ostane teologija, tj. da slijedi svoju vlastitu metodu, kao što to sve ostale znanosti čine, te da time zapravo bude autonomna i pod što manjim utjecajem drugih znanosti. Mogli bismo reći da je današnji status teologije na današnjim sveučilištima u Hrvatskoj i Europi uglavnom tako shvaćen.

No, ne može se ne primijetiti da se teologija time ipak u određenom smislu otuđila od same sebe. Čini se da je ona danas sve manje tuđinkom na sveučilištu, a tako sve više tuđinkom samoj sebi. Ona se reducirala te i danas reducira na skolastički, udžbenički prikaz vjere, kao i na puku metodologiju. Dobiva se dojam da je teologija

\footnotetext{
${ }^{5}$ Vidi H. U. von BALTHASAR, Philosophie, Christentum, Mönchtum, u: ISTI, Sponsa Verbi. Skizzen zur Theologie II, Einsiedeln, 1961., 349.-387.; ISTI, Teologija i svetost, u: Hercegovina franciscana 4(2008.)4, 161.-179.; I. IVANDA, Teologija i svetost u djelu Hansa Ursa von Balthasara, u: I. RAGUŽ (ur.), Za tragovima Božjim. Teološka traganja Karla Rahnera i Hansa Ursa von Balthasara, Đakovo, 2007., 313.-327.; E. PRZYWARA, Logos - Abendland - Reich - Commercium, Düsseldorf, 1964., 83.-94.
} 
smetnula s uma da je ona znanost vjere, a to znači da ona ne može i ne smije biti reducirana na skolastički, udžbenički i metodološki prikaz vjere, kako je to danas slučaj. Teologija ostaje teologija samo kao znanost vjere, a to znači da spoznaja, koju teologija donosi o sadržajima, otajstvima vjere, nikada ne može i ne smije ukinuti vjeru. Teološka spoznaja ne ukida otajstva vjere, nego ih kao takvima promišljajući čuva i čuvajući promišlja. U tom smislu u teologiji nije ideal da teološki pojmovi budu $\gg$ jasni i razlikovni $\ll$ (clare i distincte, Descartes), nego takvi da oni sami odišu i bivaju prožeti otajstvima vjere koji se ne ukidaju u znanju, koji zapravo i dalje ostaju i trebaju ostati »sablazan i ludost « $(1$ Kor 1,23), izazov razumu. Iz toga proizlazi da teologija, kao znanost vjere, ne može njegovati strogu razumsku metodologiju, ona će uvijek u sebi imati mističnu, sapijencijalnu, mudrosnu dimenziju, koja svjedoči o tome da njezini principi izmiču krajnjoj spoznaji i ukidanju u znanju, da sadržaji vjere zahtijevaju cjelovitu predanost osobe, vjeru djelotvornu ljubavlju (usp. Gal 5, 6). Zapravo, teologija na neki način uvijek treba ostati sacra pagina, tj. takva znanost koja treba slijediti onu metodu koja se nalazi u samom Sv. pismu. Kako Bog u svojoj objavi koristi $\gg$ metodu $\ll$ prispodoba i slika, »metodu $\ll$ koja zapravo čuva otajstvenost samoga Boga, i teologija treba razvijati tu dimenziju, donositi spoznaju koja će više nalikovati prispodobama i slikama, a ne $\gg$ uzvišenoj besjedi ili mudrosti $\ll(1$ Kor 2,1$)$ određene filozofije i određenoga razuma. Teologija treba više osluškivati i slijediti nutarnji ritam prispodoba i slika koje donosi Sveto pismo, predstavljati njihovu poruku, sadržaj, logiku i povezanost, ne ukidajući ih u znanju, u znanstvenom sustavu, nego puštajući im da uvijek daju dalje za misliti.

Zato postaje razumljivo da se većina velikih teologija modernoga doba pojavila izvan akademskoga, skolastičkoga sustava. Dovoljno se sjetiti tübingenške teološke škole 19. stoljeća, gdje je teologija svjesno u svojoj metodi učinila odmak od racionalizma, ili teologije otajstava Matthiasa Scheebena koja izlazi iz uobičajenoga skolastičkog, metodološkog bavljenja teologijom. U 20. stoljeću dvojica pak velikih teologa, Karl Barth i Hans Urs von Balthasar, nisu nikad doktorirali teologiju, a potonji nije nikad ni predavao teologiju na učilištu. To vrijedi i za Karla Rahnera, čija su promišljanja gotovo u cijelosti nastala izvan skolastičkoga, metodološkoga konteksta, uglavnom kao prigodna predavanja povezana s određenim temama. Dakako, time se ne želi reći da teologija ne može i ne treba biti znanost, odnosno da se ona treba pretvoriti u nekakvo svojevoljno i površno nabrajanje otajstava bez ikakva njihova razumijevanja. To bi bilo protivno samoj ideji Božje objave u Isusu Kristu, jer je Isus Krist Logos, Riječ. Stoga spoznaja Božje objave ne može i ne smije biti kaotična. Ona je »logična «, ona u sebi »sabire « (legein - sabirati) određene spoznaje, koje doduše nikad ne mogu iscrpiti otajstvo samoga Boga (Augustin: si comprehendis, non est Deus), Boga koji uvijek ostaje »nadspoznatljiv «, ali upravo u toj nadspoznatljivosti poticaj i izazov za čovjekovu spoznaju (usp. Ef 3, 19). 
Imajući u vidu rečeno, vidljivo je zašto je teologija tuđinka na sveučilištu. No, upravo takva tuđinka bila je pokretač same ideje sveučilišta. Naime, europska ideja sveučilišta duguje svoje početke ponajprije teologiji, odnosno kršćanstvu i Crkvi. Naime, kršćanska je teologija sekularizirala svijet, ukoliko je svijet Božje stvorenje, stvorenje koje upravo zato što je stvoreno u sebi krije tragove Boga Logosa, Trojedinoga Boga. U tom smislu teologija je bila glavni pokretač za znanstveno istraživanje svijeta, ukoliko se od vjernika zahtijeva da u ovom vidljivom svijetu, u njegovoj strukturi, prepoznaju ne samo vječne ideje, kao u Platona, nego samu prisutnost Boga, sjemenke onoga Logosa po kojemu je stvoren svijet. Unutar kršćanstva znanost je zbog toga na neki način zadobila veliku važnost, postala je neka vrsta kulta: istražujući Božje stvorenje, otkrivajući svo bogatstvo stvorenja, čovjek odaje počast samome Bogu. Zato ne treba čuditi da prva sveučilišta nastaju pod okriljem Crkve. Teologija je zato glavni pokretač ideje sveučilišta.

Isto tako, teologija je pokretač sveučilišta, ukoliko je ona kao znanost vjere, za razliku od ostalih znanosti, posebno svjesna svoje vlastite ograničenosti, ograničenosti koja zahtijeva universitas mnogobrojnih teologa, teologija, teoloških škola sada i tijekom povijesti. Drugim riječima, istinska teologija moguća je samo kao universitas, samo kao sveučilište u malome. Stoga je teologija poimanje svoje vlastite znanstvenosti proširila i na ostale znanosti. Tako svaka pojedina znanost, da bi bila i ostala istinska znanost, treba biti svjesna svojih ograničenja, ali isto tako i potrebita drugih znanosti koje mogu i trebaju obogaćivati i proširivati njezine vlastite spoznaje. U tom smislu teologija je također glavni pokretač ideje sveučilišta.

Iz svega rečenoga postaje razumljivo da su teologiju kao tuđinku mogli izbaciti samo oni totalitarni sustavi, kao što je komunizam, koji su htjeli u cijelosti zanijekati povijest nastanka sveučilišta, ali odbaciti samu ideju sveučilišta. Naime, ideja je sveučilišta uvijek podrazumijevala da sveučilište okuplja sve znanosti, znanosti koje istražuju cjelokupnu zbilju, cjelovitoga čovjeka, čovjeka u njegovoj tjelesnoj i duhovnoj stvarnosti, a to znači i čovjeka kao religiozno biće. U komunizmu se upravo to htjelo poništiti, htjelo se stvoriti potpuno novo društvo, društvo koje bi čovjeka u cijelosti lišilo njegove transcendentne i religijske dimenzije, gdje bi čovjek bio reduciran na materiju, gdje bi mogao i trebao biti pozitivistički mjerljiv. Stoga je posve jasno da unutar takvoga totalitarnog poimanja čovjeka i društva teologija nije mogla imati mjesta.

\section{Uloga teologije tuđinke na sveučilištu}

Ne ulazeći u ostale detalje, sada se možemo posvetiti posebnom doprinosu teologije na današnjem sveučilištu. 
1. Teologija čuva filozofsku bit samoga sveučilišta, a to je istraživanje znanja zbog znanja. ${ }^{6}$ Time se ne želi reći da sve znanosti jesu i trebaju biti filozofija. Ostale se znanosti bave i trebaju baviti pojedinačnim vidovima zbilje, ali ono što te znanosti čini sveučilišnima jest upravo njihova filozofijska, teorijska dimenzija. Da bismo to što zornije objasnili, treba ukazati na bitnu razliku između znanosti na sveučilištu i u tvrtkama. Tvrtka lišava znanstvenika slobode, čini ga funkcionarom. Naime, znanstvenik je podređen projektima i zahtjevima određene tvrtke. Ne može se slobodno posvetiti znanosti, odnosno »teoriji $\ll$. Njegova je »teorija « uvijek vođena interesima određenoga poduzeća ili tvrtke. On i dalje ostaje »znanstvenik «, premda je zanimljivo uočiti kako se za takve osobe rijetko rabi taj pojam. Uglavnom ih se naziva zaposlenicima, odnosno funkcionarima. To dakako ne govori ništa protiv znanstvenosti i znanstvenika koji su zaposleni u tvrtkama. Nama je samo stalo istaknuti bitnu razliku između sveučilišnoga i poslovnoga bavljenja znanošću. $\mathrm{Za}$ razliku od »znanstvenika « zaposlenog u tvrtki, sveučilišni znanstvenik u sebi ima filozofsku, teorijsku dimenziju: motri, propituje i spoznaje određeno područje svojega istraživanja bez interesa. Zanima ga uvid u objekt kao takav, on ga istražuje onkraj svake koristi i svrhovitosti. Ono praktično i praktične posljedice istraživanja zapravo ga istinski ne zanimaju. Time se ne želi reći da sveučilišne znanosti nemaju praktičnih posljedica. Naprotiv, čini se da su znanosti imale i najviše uspjeha u praktičnoj primjeni upravo tada kada su bile najslobodnije i najteoretskije.

Ali, postoji opasnost da tako shvaćene znanosti odbace svoje izvorno »filozofsko« poslanje, odnosno da podlegnu, biblijski rečeno, onim dvjema kušnjama kojima je bio izložen Isus Krist u pustinji: uhljebljenje i moć (usp. Mt, 4, 1-11). Tim su kušnjama izloženi svi ljudi pa tako i znanstvenici.

Prva kušnja glasi: »Tada mu pristupi napasnik i reče: 'Ako si Sin Božji, reci da ovo kamenje postane kruhom.' A on odgovori: 'Pisano je: Ne živi čovjek samo o kruhu, nego o svakoj riječi što izlazi iz Božjih usta.' $S$ obzirom na prvu kušnju, kušnju pretvaranja kamenja u kruh, može se reći da i znanstvenici mogu podleći đavolskoj napasti da im na sveučilištu nije više stalo do »riječi $\ll$, do znanja, do posvećenosti znanju zbog znanja, nego isključivo pretvaranju znanja u vlastiti kruh, kao načinu skrbi za vlastito preživljavanje i preživljavanje svoje obitelji. Tako na sveučilištu možemo imati ugodne i zanimljive osobe, ali krajnje loše znanstvenike, koji su na sveučilištu ne zbog znanosti, nego zbog vlastita preživljavanja. No, to je kraj i smrt znanosti i sveučilišta.

Druga kušnja glasi: »Đavao ga onda povede na goru vrlo visoku i pokaza mu sva kraljevstva svijeta i slavu njihovu pa mu reče: 'Sve ću ti to dati ako mi se ničice po-

$\overline{{ }^{6} \text { Više o tome I. RAGUŽ }}, \mathrm{O}$ »teoriji i sveučilištu nekoć i danas, 383.-391. 
kloniš.' Tada mu reče Isus: 'Odlazi, Sotono! Ta pisano je: Gospodinu, Bogu svom se klanjaj i njemu jedinom služi!' « (Mt 4, 10) Sveučilište se, prema ovom biblijskom tekstu, može pretvoriti u mjesto borbe za moć, gdje znanstvenicima nije stalo do znanja, nego do »kraljevstva svijeta i slave «, tj. do društvene moći, društvenoga prestiža i privilegija. Znanstvenici više ne žele »služiti«, kako nam kazuje biblijski tekst, tj. služiti znanju, a onda sveučilištu, učilištu i ponajprije samim studentima. ${ }^{7}$

Naposljetku, koliko god bitan i ključan, i sam filozofijski pristup znanosti nije dostatan i može biti štetan za same znanosti, a onda i za samo sveučilište, ako postane isključivi pristup. Radi se o sljedećem. Neke znanosti istražuju ono što je izvan čovjeka, prirodu kao što su prirodoslovne znanosti, ili pak neke vidove čovjekova postojanja, kao što su humanističke znanosti. Svaka pojedinačna znanost uvijek se usredotočuje na pojedinačan objekt svojega istraživanja, njega istražuje i proučava zbog njega samoga. To je potpuno ispravno i u skladu s filozofskom, teorijskom idejom znanosti kao takve. No, u tom filozofijskom pristupu znanostima krije se opasnost da se pojedinačno znanje određene znanosti apsolutizira, da se svijet i čovjeka tumači isključivo $s$ gledišta pojedinačne znanosti ili nekoliko znanosti. Tako se svijet može isključivo razumijevati kao fizički svijet, ili pak čovjek isključivo kao biološko biće. Kako se teologija bavi objektom koji je u sebi kao takav neistraživ, »koji se uvijek traži da bi se našao, ali kad ga se nađe uvijek ga se dalje traži - a to je

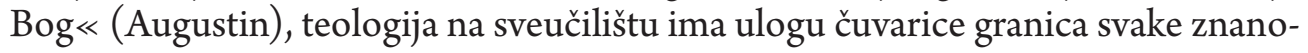
sti, ona ne dopušta da se pojedinačna znanost apsolutizira, svaku znanost podsjeća

\footnotetext{
${ }^{7}$ Zato je Karl Jaspers s pravom istaknuo da država ima pravo nadzirati, a onda i miješati se u sveučilište, i to onda kada je samo sveučilište izgubilo svoje izvorno poslanje. Primjerice, kada se nerazborito i pogrešno raspolaže novcem, ili kada je, kako smo istaknuli, znanstvenicima više stalo do uhljebljenja i moći, a manje do istinskoga znanja i prenošenja znanja studentima. Dakle, ne postoji apsolutna autonomija sveučilišta, jer je sveučilište dio cjelokupnoga društva, o kojemu ono samo također ovisi i spram kojega treba biti odgovorno. Dakako, državna se vlast ne smije miješati u život sveučilišta na način koji je protivan ideji sveučilišta: politikantstvo, kapitalizam, menadžerstvo itd. (Vidi o tome K. JASPERS, Die Idee der Universität, Berlin - Heidelberg, 1946., 105.-111.) Mogli bismo reći da je država za sveučilište ono što je analoški gledano crkveno učiteljstvo za teologiju. Kao što se crkveno učiteljstvo počinje miješati u stvar teologije kada se teologija počinje udaljavati od svojega vlastita pitanja (hereze, pokušaj apsolutnoga rješavanja određenih pitanja koja se ne mogu lako razriješiti), tako se i država isto miješa u područje sveučilišta, ako ono kao takvo izgubi svoje vlastito poslanje. I tu se može također vidjeti veliki utjecaj koji je teologija ostavila na europsko razumijevanje sveučilišta. Pritom treba reći da je posve krivo shvaćanje ono koje tvrdi da je teologija neka vrsta »partijske znanosti «, da ona slijedi samo ono što joj crkveno učiteljstvo naređuje da misli. Teologiji crkveno učiteljstvo samo postavlja okvire, ali nikako ne ukida slobodu mišljenja koja dakako ne može biti apsolutno shvaćena, jer ta sloboda prestaje tamo gdje se ugrožava život zajednice, Crkve. No, to isto vrijedi i za svaku znanost. Tamo gdje bi određena znanost donosila zaključke koji su u potpunoj suprotnosti s određenom društvenom i političkom zajednicom (primjerice, protiv demokratskoga poretka), očito je da ni kod tih znanosti ne vrijedi apsolutna sloboda mišljenja kao ni u teologiji.
} 
na njezina ograničenja, tj. da je svaka znanost samo jedna od znanosti, da nije i ne smije biti isključiva. Tako teologija na sveučilištu sve znanosti podsjeća na krajnju krhkost i ograničenost svakoga pojedinog znanja o stvarnosti i o čovjeku.

2. Filozofijski pristup znanosti i sveučilištu također je problematičan is drugog gledišta. Naime, postoji opasnost da sveučilište izgubi iz vida sam subjekt istraživanja,

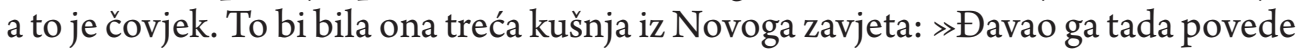
u Sveti grad, postavi ga na vrh Hrama i reče mu: 'Ako si Sin Božji, baci se dolje! Ta pisano je: Anđelima će svojim zapovjediti za tebe i na rukama će te nositi da se gdje nogom ne spotakneš o kamen.'« (Mt 4, 5-6) Radi se o kušnji taštine znanstvenika. Znanstvenici se na sveučilištu mogu smatrati $\gg$ sinovima Božjim «, ukoliko to svoje »božansko sinovstvo « vide isključivo u znanju, znanje uzimaju kao jedino mjerilo humanosti, jedini kriterij bivanja čovjekom. No, takav bi pristup bio krajnje poguban i štetan ne samo za razumijevanje čovjeka, nego za samo sveučilište. Pogledajmo o čemu se radi.

Čovjeka se može tumačiti filozofski, teorijski, ukoliko je on biće mišljenja i znanja, biće koje je posvećeno znanju zbog samoga znanja. Takav pristup ostvaruje se ne samo u znanostima nego i u religiji, jer je vjernik pozvan ulaziti u zajedništvo $s$ Bogom zbog samoga Boga. No, čovjek nije samo biće koje misli i spoznaje. On je također biće koje djeluje, društveno biće, biće zajednice, s jedne strane, ali je on isto tako i biće koje ljubi, a to znači biće intimnoga, obiteljskoga zajedništva, s druge strane. Imajući u vidu ovu drugu opasnost sveučilišnoga, akademskoga, uloga je teologije vrlo važna. Teologija, koja ima za svoj temeljni preduvjet ljudskost, etičnost (vjera i ljubav), čuva humanost sveučilišta, ukoliko upozorava sveučilište da ono lako može postati mjesto nehumanosti tamo gdje iz vida izgubi ljudsko: djelovanje i ljubav. A kao što smo rekli, ljudsko se ne da svesti na znanje. Ljudsko podrazumijeva djelovanje i ljubav.

Pod djelovanjem mislimo na ljudski čin shvaćen kao djelo, djelo kojim se zahvaća i mijenja stvarnost. Za razliku od mišljenja koje je individualno i gdje se stvarnost samo misli, djelovanje mijenja stvarnost i zahtijeva zajednicu, a time odnos s drugima, bilo s gledišta upravljanja nad drugima, bilo s gledišta suradnje s drugima, $\mathrm{s}$ kojima se jedino i može mijenjati stvarnost. U oba pak slučaja stvarnost se, dakle, mijenja djelovanjem. Takvo je djelovanje u mnogočemu zahtjevnije od mišljenja. Ono uključuje uvijek drugu osobu, podrazumijeva nepredvidivost odnosa s drugim, kao i krhkost, ograničenost samih djelatnika. Ovdje nas ne zanima podrobnija analiza čovjekova djelovanja, nego samo želimo upozoriti kako na sveučilištu mora postojati znanost koja na poseban način tematizira čovjeka kao biće djelovanja, i to ne samo teorijski, jer teorijski čovjeka kao biće djelovanja proučavaju mnoge znanosti, osobito društvene. Sveučilištu je pak potrebna znanost koja je stvarno i 
praktično znanost zajednice, koja izrasta iz žive zajednice, a to je, kako smo vidjeli, upravo teologija, jer je ona znanost Crkve. Teologija kao znanost proučava Boga koji djeluje u svijetu, koji mijenja svijet, Boga koji u Isusu Kristu djeluje tako da stvara zajednicu, svoje Tijelo, Crkvu. Ali teologija se, kao znanost Crkve, ostvaruje u stvarnom životu Crkve kao zajednice, kao zajednice onih koji vjeruju u Isusa Krista. U tom je smislu teologija najpraktičnija znanost, znanost koja opstoji jedino zahvaljujući zajednici, Crkvi. Stoga teologija ima ulogu na sveučilištu da svim znanostima doziva u svijest i tematizira činjenicu da se čovjekova humanost ne mjeri samo mišljenjem i znanjem, nego djelovanjem: čovjek ostaje čovjekom i kao djelatni subjekt, kao subjekt zajednice, kao onaj koji treba biti sposoban djelovati zajedno s drugima, surađivati s drugima i tako mijenjati ovaj svijet. Teologija je $s$ tog gledišta čuvarica humanosti na sveučilištu, ona upozorava da čovjek ostvaruje humanost kroz djelovanje u konkretnoj zajednici.

No, čovjek nije samo djelatnik, on je ljubitelj, služitelj. Nije dovoljno za čovjeka da samo misli i djeluje, nego čovjek sebe ostvaruje po odnosu s drugim, točnije po odnosu ljubavi s drugim, a to je u kršćanskom shvaćanju život u intimnoj zajednici, braku, obitelji. To znači da čovjek ostaje humanim samo kao su-čovjek, kao onaj koji se ostvaruje po ljubavi prema drugomu, po služenju drugomu u intimnom zajedništvu. Stoga je za čovjeka prijeko potreban ne samo odgoj za mišljenje i odgoj za djelovanje, nego i odgoj za ljubav prema drugomu, odgoj za služenje drugomu. U kršćanskoj vjeri, što tematizira teologija i kojoj je to jedini uvjet znanstvenosti, govori se o čovjeku kao biću ljubavi prema Bogu i prema bližnjemu, biću služenja Bogu i bližnjima. Naime, u teologiji se promišlja Boga koji se objavljuje u Isusu Kristu kao Boga koji je uzeo obličje sluge, koji je iz ljubavi odlučio biti intimno s čovjekom, odnosno koji je odlučio poništiti sebe u služenju čovjeku: »On, trajni lik Božji, nije se kao plijena držao svoje jednakosti s Bogom, nego sam sebe oplijeni uzevši lik sluge, postavši ljudima sličan; obličjem čovjeku nalik, ponizi sam sebe, poslušan do smrti, smrti na križu.« (Fil 2, 6-8) U tom smislu Pilatov poklik Ecce homo (Iv 19, 5) jest izričaj istinske humanosti, a to je humanost shvaćena kao suhumanost, kao su-ljudskost. ${ }^{8}$ Čovjek, dakle, postaje i ostaje čovjekom u odnosu s drugim čovjekom, jedino u ljubavi i služenju drugomu. Ljubav i služenje podrazumijevaju da čovjek očituje svoju humanost po odnosu prema drugomu, tj. po tome je li sposoban za intimno zajedništvo s drugom osobom, u ljubavi i služenju, u braku i obitelji. Ljubav i služenje također pretpostavljaju da čovjek poštuje drugoga u njegovoj drugosti, označavaju slobodu od svake mržnje, osvete i prisutnosti svega

${ }^{8}$ Više o tome I. RAGUŽ, Epimeteje, 15.-18.; ISTI, Pastoralije, Đakovo, 2016., 28.-42.; ISTI, Karl Barth o Friedrichu Nietzscheu, u: Diacovensia 24(2016.)3, 441.-449., posebno 444.-448. 
zloga naspram drugoga, davanje života za drugoga, kao i spremnost na primanje od drugoga, dati se pogoditi radošću i patnjom drugoga.

Sad postaje još jasnije što bi se dogodilo kad bi sveučilište izgubilo iz vida tu dvostruku dimenziju čovjekova života koju upravo tematizira teologija: djelovanje i ljubav - služenje. Teološki rečeno, sveučilište bi se pretvorilo u tašto sveučilište, znanosti u tašte znanosti, a znanstvenici u tašte, arogantne osobe. Bilo bi to »znanje koje nadima ( 1 Kor 8,1$)$, dakle, arogantno, tašto znanje, znanje koje bi isključivalo drugoga čovjeka, znanje bez ljubavi i služenja.

S obzirom na zaborav čovjeka kao djelatnoga bića, taština sveučilišta i znanosti sastojala bi se od toga da bi se sveučilište izdvojilo iz djelovanja kao takvoga, a time iz društvenoga i političkoga života. Vidjeli smo da sveučilište u svome izvornom poslanju ne smije biti mjesto vođenja politike, ostvarivanja puke društvene uslužne djelatnosti ili podređeno interesima društva, posebice kapitala. Ali isto tako ono ne smije biti potpuno odvojeno od društvenoga i političkoga života, jer bi se time mogla donositi određena znanja koja bi mogla ugrožavati i dovoditi u pitanje sam društveni i politički poredak. ${ }^{9}$ Dovoljno se samo sjetiti određenih znanstvenih spoznaja koje su tijekom povijesti dolazile sa sveučilišta te imale ulogu utemeljenja totalitarnoga društva. U tom smislu posebna je zadaća teologije na sveučilištu da bude čuvarica humanosti sveučilišta i svake znanosti. Jer, teologija uvijek ima pred sobom konkretnoga čovjeka, čovjeka koji djeluje zajednici, Crkvi, u društvu i politici. Zato ona treba upozoravati znanosti posebno onda kada su one u opasnosti da ugrožavaju društveni i politički poredak određene zajednice. To teologija ne treba činiti eksplicitno, nego implicitno, samim time što proučava konkretnoga čovjeka, čovjeka kako ga razumije Božja objava u Isusu Kristu, odnosno konkretna zajednica koja je Crkva. Svojim promišljanjima o djelatnom čovjeku, čovjeku zajednice, Crkve, teologija može i treba imati kritičku i korektivnu ulogu spram ostalih znanosti, odnosno činiti ih društveno i politički osjetljivima, a znanstvenicima osvješćivati da oni nisu izolirani, atomizirani subjekti bez zajednice. ${ }^{10}$

${ }_{9}^{9}$ Zato s pravom veliki njemački poznavatelj europske kulture Ernst Robert Curtius piše, u djelu koje je nedavno prvi put posthumno objavljeno, da je jedna od presudnih kreposti obrazovanja, a time i sveučilišta, »osjećaj za zajedničko « (Gemeinsinn). Osjećaj za zajedničko jest izlaženje iz uskoga kruga vlastita života u zajednicu, tj. osjetljivost za zajednicu. $S$ tim je usko povezana i krepost velikodušnosti, koju Curtius shvaća kao moralnu osjetljivost ne samo »za svoje malo ja, nego za sve ljude koji su s njime povezani ili su mu podređeni.« (E. R. CURTIUS, Elemente der Bildung, München, 2017., 150.)

${ }^{10}$ Zanimljivo je da Jaspers ulogu sveučilišta uspoređuje s Crkvom. Kao što je Crkva istodobno univerzalna i nadnacionalna, tako i sveučilište treba biti istodobno univerzalno, ono koje služi cijelom čovječanstvu (sveučilišni znanstvenik kao predstavnik cijeloga čovječanstva), ali i nacionalno, ukoliko se ostvaruje u konkretnom društvu, konkretnoj državi. (K. JASPERS, Die Idee der Universität, 
To isto vrijedi i za ljubav i služenje. Sveučilište se može pretvoriti u mjesto nehumanosti, ukoliko znanstvenici, baveći se isključivo znanjem, izgube iz vida ljubav prema drugomu, služenje drugomu, u braku, obiteljima i prema svim ljudima. Tako se događalo i uvijek se iznova događa da znanstvenici budu vrhunski znanstvenici, a pritom vrhunski nehumani, krajnje nesposobni živjeti s drugima, niti ljube niti služe čovjeku. A da ne spominjemo nedostatak poniznosti, oholi stav spram ostalih ljudi. Ne treba ni spominjati koliko takvi znanstvenici mogu negativno utjecati na mladež kao osobe nemoralnoga života, ili koliko mogu sa svojim spoznajama, posebice u prirodnim znanostima, koje uopće ne vode računa o ljubavi i služenju, opasno utjecati na čovjeka. I ne samo to. Sveučilištu je svojstveno kritičko istraživanje znanja, a to nije moguće bez rasprave, prijepora i uzajamnih kritika među znanstvenicima. Često se pak događa da se sveučilišno ozračje, koje bi trebalo biti istraživanje kroz raspravu, prijepore u uzajamnom poštovanju, pretvara u bespoštednu borbu na život ili smrt, gdje znanstvenik, koji drukčije misli, prestaje biti kolega i postaje smrtni neprijatelj. Sveučilište tako može postati mjesto gdje znanstvenici imaju za cilj potpuno poništenje drugoga znanstvenika. Da se sve to ne dogodi na sveučilištu, teologija treba imati ulogu čuvanja humanosti, humanosti shvaćene kao su-humanosti, poštovanja i podnošenja drugoga u ljubavi, poniznosti protiv svake oholosti koja prezire i ljubav i služenje. ${ }^{11} \mathrm{Jer}$, sveučilište nije borba jednih protiv drugih, nego zajedničko traganje za istinom, i to traganje uvijek u ljubavi prema drugomu, kako piše sv. Pavao: »Istinovati u ljubavi.« $(\mathrm{Ef} 4,15)$ Gdje nema »istinovanja u ljubavi«, istina postaje idol (Pascal), tj. znanost postaje izričaj moći, a sveučilište mjesto obračunavanja jednih protiv drugih. Zato je i ovdje uloga teologije presudna, ona čuva i njeguje humanost sveučilišta i ostalih znanosti,

115.) Nadovezujući se na Jaspersovu misao, možemo reći da je i s tog gledišta teologija, osobito katolička teologija, ona znanost na sveučilištu koja na poseban način doziva u svijest univerzalnost svakoga sveučilišta, ali i njegovu nacionalnost, tj. konkretizaciju unutar života određenoga društva, države i nacije. Ili drukčije rečeno, svako sveučilište treba biti nadnacionalno (ne smije biti podređeno interesima nacije), ali ne smije biti anacionalno ili još gore, antinacionalno.

${ }^{11}$ Ovako o tome piše Curtius: »Ne zaboravimo i posljednju krepost koja nije samo krepost obrazovanja, ali koja je kao takva od posebne važnosti za obrazovanoga čovjeka i koju on upravo zato vrlo lako previđa. Ta jednostavna krepost nije nikoja druga negoli poniznost. Poznato je da posjedovanje obrazovanja i vrijednost obrazovanja mogu dovesti do umišljenosti i oholosti obrazovanja. Čovjek zdrave pameti zasigurno će se kloniti takvih pogrešaka. No, daleko će se teže protiviti tomu da svoju vrijednost obrazovanja shvaća kao nadmoć, kao aristokratsku nedodirljivost. Osjećaj za zajedničko nije dovoljan da se prevlada takva suženost. Ovdje se zahtijeva nešto dublje, nešto u najvišem smislu asocijalno, ili bolje rečeno, nešto nadsocijalno, ili još bolje, nešto transcendentno. Što je čovjek obdareniji dobrima i vrijednostima, tim se više treba poniziti spram neizrecivoga. Treba se poniziti ne samo javnim gestama u Crkvi, nego također tihim razmatranjem i ispitivanjem svoje nutrine, tu mislim na nutarnje odaje vlastite duše i svojega doma.« (E. R. CURTIUS, Elemente der Bildung, 151.) 
ona neprestano progovara o humanosti kao su-humanosti, o čovjeku koji ostaje čovjekom samo ukoliko je sposoban ljubiti i služiti. Teološka znanost na sveučilištu podsjeća sve znanstvenike da za humanost čovjeka nije dovoljno biti samo dobar znanstvenik, nego i dobar čovjek, da biti human, biti čovjek znači biti su-čovjek, osoba ljubavi i služenja. Bez tako shvaćene humanosti sveučilište i znanosti postali bi besmisleni, jer su nehumani.

\section{Umjesto zaključka}

Iz našega promišljanja vjerujemo da je postalo vidljivo na koji način teologija jest ili bi trebala biti istinska čuvarica ideje sveučilišta. Kako smo istaknuli, to će ona moći samo ako ostane vjerna svojoj vlastitoj metodi, metodi koja ju čini tuđinkom na sveučilištu. Teologija je pak kao tuđinka istodobno »izvan «i $\gg$ unutar sveučilišta «. Ona je »izvan sveučilišta « ukoliko tematizira cjelovitoga čovjeka u odnosu spram Boga, čovjeka koji se ne može i ne smije reducirati na samo znanstvenost. U tom smislu teologija na sveučilištu spasonosno čuva to »izvan « sveučilišta, postavljajući mu ograničenja, ograničenja koja proizlaze iz same humanosti. Jer, sveučilište bez ograničenja, koje bi si uzimalo za pravo da čovjeka isključivo tumači znanstveno, postalo bi mjesto nehumanosti, uzrokovalo bi s pravom veliko razočaranje, bilo bi predmetom mržnje i prijezira. Teologija je također $\mathrm{i} \gg$ unutar « sveučilišta. Kao takva ona potiče sveučilište da ono zaista bude i ostane istinsko mjesto znanja, mjesto istraživanja znanja zbog znanja, a ne zbog nekih drugih interesa, podređena onim trima kušnjama iz Novoga zavjeta. Karl Jaspers upozorio je da znanstvenici često zaboravljaju da i znanost treba $\gg$ vođenja $\ll .{ }^{12}$ Usudili bismo se reći da bi upravo teologija trebala imati takvu ulogu vođenja na sveučilištu, dakako vođenja u smislu Kristova vođenja, a to je ljubav i služenje. Teologija na sveučilištu na tom bi se tragu mogla shvaćati kao sluškinja ostalih znanosti, kao sluškinja koja »vodi« sve znanosti: »vodi « ih da ne izgube svoje vlastito dostojanstvo, da ne prestanu biti znanosti (prva opasnost); »vodi « ih tako da ne postanu apsolutističke, tašte, lišene djelovanja i življenja u konkretnoj zajednici, ali i da ne budu nehumane, bez ljubavi i služenja - etičnosti (druga opasnost). Jednom riječju, teologija na sveučilištu treba »voditi « znanosti da budu i ostanu znanosti, i to humane znanosti koje proslavljaju Boga i čovjeka, služe Bogu i čovjeku u ovom svijetu.

Naposljetku, treba također reći da je uloga teologije važna i za samo sveučilište $s$ gledišta uloge religije u današnjem društvu. Naime, svjedoci smo danas ponovnoga buđenja religije. $S$ tim je uvijek povezana opasnost da se religija, a i samo kršćanstvo, pogrešno razumije, da ga se zloupotrijebi za razne osobne, društvene i političke interese. Stoga teologija ima važnu kritičku i korekcijsku ulogu spram same

${ }^{12}$ K. JASPERS, Die Idee der Universität, 23. 
religije, a time kršćanstva i Crkve. Kršćanska teologija protivi se svim onim koncepcijama religije gdje se ugrožava poimanje i življenje religije kao agape, kao ljubavi. Teologija pak progovara o Bogu koji se, kako smo naznačili, »oplijenio«, poništio samoga sebe iz ljubavi prema čovjeku. To je, dakle, Bog silazne putanje, Bog koji ljubi čovjeka, ovu zemlju. Takav Bog kazuje da čovjek ostvaruje samoga sebe samo ako i sam živi u tom ritmu silazne putanje: od Boga prema čovjeku. Stoga svaka religija, koja se udaljuje od takvoga ritma, koja prekida taj ritam silazne putanje, ljubavi i služenja, postaje problematična za kršćanstvo, Crkvu, ali i samo društvo. U tom je smislu teologija itekako važna na sveučilištu, kao kritička znanost o religiji i njezinoj ulozi u današnjem svijetu. 


\title{
ON THEOLOGY AT THE UNIVERSITY
}

\author{
Ivica RAGUŽ*
}

Summary: The article analyses the position and importance of theology at the university. By pointing to the particularity of theology as a science, the first part determines the true place of theology at the university, that is, it establishes theology as an alien at the university. This is to point out that theology, if it wants to remain faithful to itself, to become alienated from itself and contribute to the university, it must remain foreign to that same university. This view also serves to critically observe the contemporary theological science. The second part of the paper shows the particular contribution of theology to the university and thus points to its importance. The basis of these reflections is Christ's triple temptation. In the first place, theology keeps the philosophical crux of the university - the research of knowledge for knowledge sake. Such a view is set against needless staffing and creating functionaries in science, but also against the exclusiveness of the philosophical approach of science, that is, the absolutizing of certain sciences. The philosophical approach to science is also in danger of losing focus from the subject of research - man. The contribution of theology here is manifested in its corrective role: it reminds the sciences not to lose sight of what is implied by humanity - action and love. It is the intention of this article, through reflection on theology at the university and its contributions, to illuminate and show how theology is or should be the true keeper of the idea of the university.

Keywords: theology, university, science, knowledge, action, love.

\footnotetext{
* Full Prof. Ivica Raguž, Ph. D., Catholic Faculty of Theology in Đakovo, J. J. Strossmayer University of Osijek, P. Preradovića 17, 31400 Đakovo, Croatia, ivica.raguz@os.t-com.hr
} 